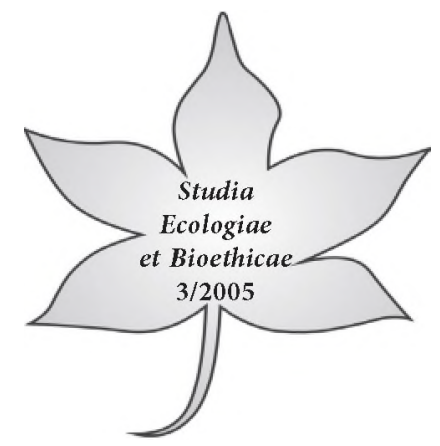

\title{
The Problems of Environmental Education in Agribusiness
}

The notion of "agribusiness" in our country emerged in shortly after the political transformation in the beginning of 1990s, partially substituting for such notions as "food economy" and "agricultural and industrial complex". Despite quite a period which has passed since then, no-one has created a coherent, scientifically verifiable definition of the notion of "agribusiness". It probably stems from the very complicated nature of a process hidden under this term. A process involving various sectors and branches of economy for which the production of food is by no means the most important process.

In literature, the notion most often comprises subjects such as: agriculture, forestry and fishery, food-processing industry, distribution and storage. This list proves that each of these branches constitutes a completely independent branch of science with its own methodology of research. An additional division from the point of view of the research methodology is created between the natural and the economic sciences. The basic principles of scientific cognition in the sphere of natural sciences cannot be directly compared with those characteristic of the sphere of economics. Therefore, the notion of agribusiness in the meaning of "food economy" does not refer to the existence of some coherent and independently existing scientific system.

From the point of view of a naturalist, the methodological principles of scientific cognition do not function with reference to the notion of agribusiness. A naturalist begins their research from posting a problem, often directly based on the observation of natural reality. Having finally defined the problem, they construct a hypothesis for solving it. Appropriate hypotheses should enable forecasting the occurrence of certain phenomena. The forecast should be based on and logically stem from the posted hypothesis. The next stage in scientific cognition is testing the hypotheses conducted through observation and properly prepared and relevant scientific experiments. Thus, a scientific experiment is every observation contributing to the verification of a hypothesis. The way in which we decide to conduct an experiment in order to obtain necessary information is called "the planning of an experiment". The information collected during the 
experiment will help decide about possible recognition of the rightness of the hypothesis posted (enabling the explanation of the phenomenon under research) or its rejection.

The principles of scientific cognition in natural areas described above require several other conditions to be meet. Among other things, we must seek facts which could possibly abolish the constructed hypothesis. It is the elimination of false concepts one after another that the scientific progress consists in. It is a process we always try to pursue, yet are never able to reach in a perfect way. From the point of view of the efficiency of the principles of scientific cognition, it would be best to formulate uncomplicated and easily verifiable hypotheses. A hypothesis which gives only the opportunity of non-limited forecasting is scientifically useless.

The main methodological problem in natural research is the complexity of the systems under research. The complexity consists, first of all, in simultaneous influence of various external factors. Notwithstanding the degree of a system's complexity, the principle of the experimental verifiability of a hypothesis is still binding.

Analyzing the necessary methodological assumptions which have to occur in order for a discipline to function and - on the other hand - become scientifically verifiable, it must be accepted that agribusiness does not meet them in any respect. Therefore, even for this reason, at the present stage there are no comprehensive scientific programmes for complex research of the issues of environmental education in agribusiness. The above mentioned subjects, i.e. agriculture, forestry and fishery, food-processing industry, distribution and storage, jointly falling into the notion of agribusiness, practically function in complete separation. They feature not only their own research methodology, but also from the practical point of view of they constitute separate branches of economy. Each of the aforementioned parts of the complex actually works independently, which means that the material benefits do not accumulate into one global profit, which only in such situation could become some additional value in the national dimension.

It would obviously be a mistake to state that all sectors constituting the notion of agribusiness do not develop as such. The sectors do develop and take advantage of the latest discoveries of science and technology, they also implement them in practice, yet the global profit from these activities is not even a sum resulting from the economic account of all the sectors falling as component parts into the notion of agribusiness. The lack of a scientifically and economically verifiable purpose common for all the sectors has so far successfully prevented us from creating valuable and comprehensive agribusiness education programmes.

Another factor preventing us from creating such programme is the tendency for merological approach (Greek 'meros' = a part), still observed in scientific research. Sticking to only this type of approach in the interpretation of the surrounding phenomena could be understood some time ago. Yet today, bearing 
in mind the state of technological development, it is high time to reformulate, following the well-known theory of the integration levels. All in all, we cannot predict the characteristic features of a superior level relying only on what we know about the inferior ones. You cannot predict about the characteristics of water, knowing only what you know about oxygen and hydrogen. What follows, you cannot predict specific features of ecological systems on the basis of our knowledge concerning the features of isolated populations. And you cannot talk about the reaction of the whole complex hidden in the notion of agribusiness having only partial information about particular components of this complex. Therefore, the key to discovering the rules governing agribusiness should be research methods based on holistic approach (Greek: holos $=$ whole).

Only the holistic approach to the agribusiness should become the basis for creating an effective educational method, so that we can avoid mistakes so easily made at the borderline of nature and economics. We all remember the first controversial theories by Malthus concerning the regulation of the number of population. Malthus claimed that the number of organisms grows geometrically $(1,2,3,4,8,16 \ldots)$ while the amount of food may grow arithmetically $(1,2,3,4 \ldots)$. It seems that the arithmetic pattern for the growth of food amounts was chosen by Malthus rather arbitrarily and maybe he treated the pace as the only possible maximum. However, the fact that there are discrepancies between the growth of population and the growth of available food must have led Malthus to an inevitable conclusion that at some point in time the reproduction must become limited by food resources. Malthus treated the conclusion as negative. How to protect populations against growing into numbers leading it to its limitation by food resources? What mechanisms inhibit the population growth and cause that, after all, it usually does not grow geometrically? It turns out that at present we still ask ourselves the same question. At least partial answer to this question must be preceded by the process known as agribusiness.

Agribusiness is a sphere of national economy giving employment to over $35 \%$ of people and producing approximately $22 \%$ of the GNP. Only this fact proves how important this sphere is for the national economy. The main economic objective of agribusiness is not to provide the necessary amounts of food, but to obtain a certain income. It appears that the growth of population does not always have to lead to a growth in the sphere of agricultural production, one of the constituents of agribusiness. Additional problem is that the number of people grows much more dynamically in poorly developed regions in which we observe economic underdevelopment (lack of modern industries, agriculture and infrastructure of the whole complex of agribusiness). In these parts of the world, we can also observe insufficiency of food. It is estimated that 700 million people all over the world suffer undernourishment and are affected by famine-related disorders. Over 1.2 billion people lives in extreme poverty. 
As can be seen, the Malthus theory, still not finally explained, is overlapped by political and other external factors which make food issues even more profound. The underdeveloped regions of the world feature very low GNP per person and thus their agribusiness investment possibilities are close to zero. Yet, mistaken would be those who - looking at the population growth (especially in the developing countries) - are sceptical about the possibility of feeding these populations. To every 1 person on the globe there is 0.9 ha of agricultural land; in Europe -0.3 ha. If we assume that 0.3 ha of agricultural land is enough to feed 1 person, then it turns out that the world has significant alimentation reserves. And the values are bound to change in the future due to technological development of agribusiness. However, the development will only be possible if all spheres constituent of the notion of agribusiness develop equally.

We must remember that the share of agriculture in the final food product accounts for $19-20 \%$, the rest is extra-agricultural activity, i.e. production and processing. Therefore, in the whole process the potential free area resources in the form of agricultural land constitute a value several times smaller than it should result from the calculations. And by no means is it related to the process of agricultural production intensification. Only after complete use of all reserves in the whole process constituting the notion of agribusiness should the laws first formulated by Quetelet and Verhulst (1838) come into force. Quetelet put forward an assumption that the factors determining the growth of population can at the same time inhibit it. Verhulst, mathematically describing the population growth as very dynamic at first and later slowing down towards zero, obtained the equation-corresponding population growth curve in the shape of the letter " $S$ ", which he called the logistic curve or logistic function. The works of Verhulst and Quetelet are fundamental for demographics or ecology itself, dealing with the problems of structure and function of floral and faunal populations.

Taking into the consideration the ideas announced by Verhulst and Quetelet, it must be in the sphere of agribusiness where we should seek the necessary reserves determining the full availability of food. Otherwise, the conditions for natural inhibition of the population growth are bound to occur.

A separate problem in building proper relations within agribusiness is a varied availability of food products. Compared to 1950, we can observe a triple growth of global agricultural production. The present global production of cereals is over 2 billion tons a year, while meat production amounts to 200 million tons.

A similar high pace of growth refers to other types of agricultural and food production. The problem lies in the fact that food resources multiply in highly developed countries (and remain there), while they are insufficient in poor countries. The elimination of territorial disproportions of global food allocation is connected with the global food distribution and trading. The world turnover of cereals amounts to 230 million tons. Yet the resources are exchanged mostly among rich countries. 
The world reserves of cereals are estimated at about 230-250 million tons a year. They serve, apart from the national needs, to counteract emergency situations, such as floods, earthquakes, war conflicts, droughts and the like. Therefore, it is impossible to compensate for the lack of cereals in the countries which need it most. A similar situation takes place in other types of food, all proportions considered.

Global food trade is subject to market rights, i.e. competition and profit, dictated by global agribusiness. Therefore, the famine we observe nowadays on our planet has nothing to do with natural rights of the environment, dependent on the limited natural resources available.

The responsibility for the situation lies both in agribusiness and the globalization of food processes controlled within economic structures functioning in cross-national dimensions.

Within the educational systems functioning nowadays, there are no comprehensive programmes of environmental education constituting the foundations of education in agribusiness in the holistic approach. At most universities and academies dealing with the issue, subjects connected with environmental education, if they do at all, exist independent subjects within the scope of, for instance, ecology, environment protection or environment resources management. Due to the lack of their joint existence within one teaching system adapted to the needs of the future agribusiness managers, next generations of graduates will only learn about the economic aspects of agribusiness. This fact dooms further development of the most significant agribusiness knowledge management process to failure from the very beginning. This time, the failure will even be more painful because it will be connected with inappropriate management of the nation's natural resources. The effects of this process can already be felt in many countries.

Certainly, one of the most significant issues in creating a comprehensive programme of environmental education for agribusiness is the aforementioned lack of a common holistic research method. The missing link to which the whole agribusiness process could refer, beginning from production, through processing, storage, transport and distribution is the production of healthy food. By systematizing the research methodology within agribusiness paying special attention to the production of healthy food, we order the whole natural process not only at the production stage, but also at subsequent stages where the only thing that counts is the "market game".

Only the marketing priorities set in the way that the primary objective will be the production of healthy food can create the foundations for the preparation of a holistic educational programme called "Knowledge Management in Agribusiness in Compliance with the Needs of the Social and Natural Environment". 
Despite formulating such far-reaching conclusions, I am quite optimistic because especially recently we may observe a growing number of instances of thinking about the agribusiness process not only in terms of economic rights, but also ever more often in terms of the needs of the natural environment and the changing needs of the customers.

The best practical example of the creation of almost perfect methods of environmentfriendly agricultural production is the project implemented by the Regional Consulting Centre in Przysiek called "The Protection of the Quality of Groundwater and Surface Water through Implementing and Popularising Good Agricultural Practices as an Element of Balanced Development of Agriculture in Rural Areas".

\section{Literature}

K. BAJAN, Agrobiznes w rolnictwie polskim. Wyższa Szkoła Społeczno-Przyrodnicza. Lublin: 2003.

K. Bajan, Agrobiznes w świecie. Wyższa Szkoła Społeczno-Przyrodnicza. Lublin: 2003.

D. Botkin, E. Keller, Environmental Science. JOHN WILEY\&SONS, INC, New York: 1995, p. 627.

Central Statistical Office. Polish Statistical Yearbook. Warszawa: 2003.

Uzytkowanie gruntów, powierzchnia zasiewów I pogłowie zwierząt gospodarskich w 2004 r., red. B.

Domaszewicz, GUS, Warszawa 2004.

Ochrona środowiska 2004, red. M. Grzesiak, M. Domańska, GUS, Warszawa 2004.

J. B. Harborne, Ekologia biochemiczna, PWN, Warszawa: 1997.

CH. J. Krebs, Ekologia, Wydawnictwa Naukowe PWN. Warszawa: 1996.

J. R. KreBs, N. B. DAviEs, Wprowadzenie do ekologii behawioralnej, PWN, Warszawa: 2001.

Ekologia i jej związki z różnymi dziedzinami wiedzy, red. A. Kurnatowska.PWN, Warszawa-Łódź: 1997.

\section{Problemy edukacji środowiskowej w agrobiznesie}

\section{STRESZCZENIE}

W ramach obecnie funkcjonujących systemów edukacji brak jest kompleksowego programu edukacji środowiskowej stanowiącego podstawy edukacji w agrobiznesie o podejściu holistycznym. Na większości uczelni wyższych zajmujących się tą problematyką, przedmioty związane $\mathrm{z}$ edukacją środowiskową w najlepszym przypadku występują $\mathrm{w}$ postaci niezależnych przedmiotów, np. ekologii, ochrony środowiska, zarządzaniem środowiskiem, zarządzania zasobami środowiska. Brak powiązania ich w jeden system nauczania dostosowany do potrzeb przyszłej kadry zarządzającej agrobiznesem powoduje, że kolejne roczniki absolwentów w ramach pojęcia agrobiznes, będą posiadać wiedzę wyłącznie z zakresu tematyki ekonomicznej. Fakt ten z góry skazuje dalszy rozwój tego najistotniejszego procesu zarządzania wiedzą w agrobiznesie na porażkę. Tym razem porażka, będzie jeszcze bardziej dotkliwa, ponieważ wiązać się będzie $z$ błędnym gospodarowaniem zasobami przyrodniczymi kraju. Skutki tego procesu w wielu krajach już są obecnie odczuwalne. 